\title{
Protist enteroparasites in wild boar (Sus scrofa ferus) and black Iberian pig (Sus scrofa domesticus) in southern Spain: a protective effect on hepatitis $E$ acquisition?
}

Antonio Rivero-Juarez ${ }^{1 \dagger}$, Alejandro Dashti ${ }^{2 \dagger}$, Pedro López-López ${ }^{1}$, Aly Salimo Muadica², Maria de los Angeles Risalde1,3, Pamela C. Köster², Isabel Machuca' , Begoña Bailo², Marta Hernández de Mingo², Elena Dacal ${ }^{2}$, Ignacio García-Bocanegra ${ }^{4}$, José M. Saugar², Rafael Calero-Bernal ${ }^{5}$, David González-Barrio 2,5,6, Antonio Rivero ${ }^{1 \dagger}$, Verónica Briz ${ }^{6 *}$ and David Carmena ${ }^{2^{*}}$ (D)

\begin{abstract}
Background: Several studies have independently evaluated the occurrence of hepatitis E virus (HEV) and enteroparasites in swine, but no surveys have been conducted to jointly assess the prevalence and genetic diversity of enteroparasites in pigs and wild boars, their sympatric transmission between hosts, and their potential interaction with HEV.

Methods: We prospectively collected serum and faecal samples from black Iberian domestic pigs and wild boars from southern Spain between 2015-2016. We evaluated for HEV in serum and faeces, and for the presence of enteroparasites (Giardia duodenalis, Cryptosporidium spp., Blastocystis sp., Neobalantidium coli and Strongyloides spp.) in the same faecal samples. The prevalence of each intestinal parasite species was calculated.
\end{abstract}

Results: A total of 328 animals (56.7\% black Iberian pigs and $43.3 \%$ wild boars) were included in the study. The overall global prevalence of HEV in serum was 16.8\%. The overall global prevalence of each enteroparasite species was 19.5\% for G. duodenalis, 8.2\% for Cryptosporidium spp., 41.8\% for Blastocystis sp., 31.4\% for N. coli, and 8.8\% for Strongyloides spp. HEV-infected animals showed a significantly lower prevalence of $G$. duodenalis (3.2 vs 20\%; $P=0.002$ ) and Blastocystis sp. (38.7 vs 80\%; $P<0.001)$ than those uninfected by HEV. Animals carrying G. duodenalis and Blastocystis sp. infections showed a significantly lower rate of HEV infection than those not harbouring these enteroparasites $(P<0.001)$.

Conclusions: Our study found a high prevalence of enteroparasites in black Iberian pigs and wild boars in southern Spain, suggesting a sympatric co-transmission of some of the species investigated. It is suggested that extracellular $G$. duodenalis and Blastocystis sp. might have a protective effect on HEV acquisition in swine.

Keywords: Hepatitis E virus, Enteric parasites, Cryptosporidium, Giardia, Blastocystis, Strongyloides, Transmission, Pigs, Wild boars, Co-infection, Spain

*Correspondence: veronica.briz@isciii.es; dacarmena@isciii.es

${ }^{\dagger}$ Antonio Rivero-Juarez and Alejandro Dashti contributed equally to this study

2 Parasitology Reference and Research Laboratory, Spanish National Centre for Microbiology, Majadahonda, Madrid, Spain

${ }^{6}$ Viral Hepatitis Reference and Research Laboratory, Spanish National Centre for Microbiology, Majadahonda, Madrid, Spain

Full list of author information is available at the end of the article

\begin{abstract}
Background
The intestinal protozoans Giardia duodenalis and Cryptosporidium spp. are major contributors to the burden of diarrhoeal disease in humans and livestock species globally $[1,2]$. Both parasites are transmitted via the faecal-oral route either indirectly through ingestion
\end{abstract}

c) The Author(s) 2020. This article is licensed under a Creative Commons Attribution 4.0 International License, which permits use, sharing, adaptation, distribution and reproduction in any medium or format, as long as you give appropriate credit to the original author(s) and the source, provide a link to the Creative Commons licence, and indicate if changes were made. The images or other third party material in this article are included in the article's Creative Commons licence, unless indicated otherwise in a credit line to the material. If material is not included in the article's Creative Commons licence and your intended use is not permitted by statutory regulation or exceeds the permitted use, you will need to obtain permission directly from the copyright holder. To view a copy of this licence, visit http://creativeco mmons.org/licenses/by/4.0/. The Creative Commons Public Domain Dedication waiver (http://creativecommons.org/publicdomain/ zero/1.0/) applies to the data made available in this article, unless otherwise stated in a credit line to the data. 
of contaminated water or food or directly by contact with infected persons or animals. Consequently, waterborne and foodborne outbreaks of cryptosporidiosis and giardiosis in humans are frequently reported [3, 4]. The stramenopile Blastocystis sp. is the protist most frequently found colonizing/infecting the intestinal tract of humans [5]. Because asymptomatic colonization is very common and pathogenicity has not been conclusively demonstrated in vivo, the clinical significance of Blastocystis sp. remains controversial [6]. Little is known on the epidemiology of Blastocystis sp. in non-human animal species. The ciliate Neobalantidium coli is a ubiquitous parasite commonly found in domestic and wild swine, with most cases being asymptomatic [7]. The parasite is transmitted via the faecal-oral route primarily through contaminated water with cysts. Humans in close contact with pigs or their excrements may accidentally become infected. Finally, the presence of soil-transmitted helminths belonging to the genus Strongyloides seem to be a common finding in free-range pigs raised in low-income countries [8], but little or no information at all is available from swine in high-income countries including Spain.

Hepatitis E virus (HEV) is the leading cause of acute hepatitis worldwide [9]. For this reason, and together with the widespread and relatively easy transmission of the virus, HEV infection is regarded as an emerging major public health problem. HEV is an RNA virus of the family Hepeviridae with marked genetic heterogeneity. Five distinct HEV genotypes have been demonstrated to cause human infections; genotypes HEV-1 and HEV-2 infect humans alone, genotypes HEV-3 and HEV-4 primarily infect pigs, wild boars and deer, and genotype HEV-7 primarily infects camelids [10]. This enterically acquired virus is associated with large disease outbreaks associated with the consumption of contaminated water mostly in poor-resource settings characterized by little or no access to safe drinking water, and inadequate sanitation and hygiene [11]. Sporadic cases linked to pork consumption have also been reported in high-income countries [10,12]. Other sources of infection may include contact with infected organs or carcasses at the time of slaughter or during hunting and evisceration of game, or contact with manure from infected swine.

The main hosts are humans (with a seroprevalence rate ranging between 5-50\%) and pigs (with a seroprevalence rate ranging between $10-80 \%$ ) [13, 14]. In most humans and pigs HEV infections present as subclinical and selflimiting hepatitis [12]. Indeed, a worst prognosis might be observed in some populations including pregnant, liver cirrhotic, and immunosuppressed patients [15-17]. Because swine are the main host of HEV, the consumption of raw or under-cooked pork constitutes one of the main routes of transmission [10].
Despite the publication of several studies independently evaluating the prevalence of HEV and enteroparasites in swine, no surveys have been conducted to date to jointly assess the prevalence and genetic diversity of common intestinal parasite (including protozoans, stramenopiles, ciliates and helminths) species in pigs and wild boars, their sympatric transmission between host species, and their potential interaction with HEV.

\section{Methods}

\section{Study area, sampling and data collection}

We prospectively collected serum and feces samples from black Iberian domestic pigs and wild boar from Córdoba (southern Spain) between 2015-2016. Black Iberians pigs were bred in extensive farm production system, sharing habitat with the wild boar population included in the study. Sampling was conducted to determine prevalence and risk factors for HEV infection. Additional information regarding the methods and procedures involved can be found elsewhere $[18,19]$. For the purpose of the present study, we randomly selected black Iberian pigs and wild boars, stratifying the former by age and the latter by age and sex.

Prospectively, we evaluated samples for HEV in serum and faeces $[18,19]$, and, for the purpose of this study, we retrospectively assessed the presence of enteroparasites in DNA samples. An aliquot $(\sim 1 \mathrm{~g})$ of faeces was stored at $-80{ }^{\circ} \mathrm{C}$ within $24 \mathrm{~h}$ of collection until nucleic acid extraction. Extraction and purification of total nucleic acid was carried out from $200 \mu$ l of faecal supernatants using the QIAamp Cador Pathogen Mini Kit (Qiagen, Hilden, Germany). Serum samples were obtained from $5 \mathrm{ml}$ of whole blood after centrifugation at $3000 \times g$ for 10 min. Viral RNA was extracted using the QIAmp Minielute Virus Spin Kit (Qiagen). All nucleic acid extraction procedures were performed using automated equipment (QIAcube, Qiagen). DNA and RNA samples were frozen at $-80^{\circ} \mathrm{C}$ until downstream analysis.

\section{Molecular detection and characterization of Giardia duodenalis}

Initial detection of G. duodenalis DNA was achieved using a real-time PCR (qPCR) method targeting a 62-bp region of the gene codifying the small subunit ribosomal RNA (SSU rRNA) of the parasite [20]. Amplification reactions $(25 \mu \mathrm{l})$ consisted of $3 \mu \mathrm{l}$ of template DNA, $0.5 \mu \mathrm{M}$ of each primer Gd-80F and Gd-127R, $0.4 \mu \mathrm{M}$ of probe (Additional file 1: Table S1), and $12.5 \mu$ l TaqMan ${ }^{\circledR}$ Gene Expression Master Mix (Applied Biosystems, CA, USA). Detection of parasitic DNA was performed on a Corbett Rotor GeneTM 6000 real-time PCR system (Qiagen) using an amplification protocol consisting on an initial hold step of $2 \mathrm{~min}$ at $55^{\circ} \mathrm{C}$ and $15 \mathrm{~min}$ at $95{ }^{\circ} \mathrm{C}$, 
followed by 45 cycles of $15 \mathrm{~s}$ at $95{ }^{\circ} \mathrm{C}$ and $1 \mathrm{~min}$ at $60{ }^{\circ} \mathrm{C}$. Water (no template) and genomic DNA (positive) controls were included in each PCR run.

Giardia duodenalis isolates that tested positive by qPCR were subsequently assessed by sequence-based multi-locus genotyping of the genes encoding for the glutamate dehydrogenase $(g d h)$ [21], $\beta$-giardin (bg) [22], and triose phosphate (tpi) [23] proteins of the parasite. Amplifications were conducted by semi-nested and nested PCR protocols using specific primer pairs (Additional file 1: Table S1).

\section{Molecular detection and characterization of Cryptosporidium spp.}

The presence of Cryptosporidium spp. was assessed using a nested-PCR protocol to amplify a 587 bp fragment of the SSU rRNA gene of the parasite [24]. Amplification reactions $(50 \mu \mathrm{l})$ included $3 \mu \mathrm{l}$ of DNA sample and $0.3 \mu \mathrm{M}$ of the primer pairs CR-P1/CR-P2 in the primary reaction and CR-P3/CPB-DIAGR in the secondary reaction (Additional file 1: Table S1). Both PCR reactions were carried out as follows: one step at $94{ }^{\circ} \mathrm{C}$ for $3 \mathrm{~min}$, followed by 35 cycles of $94{ }^{\circ} \mathrm{C}$ for $40 \mathrm{~s}, 50^{\circ} \mathrm{C}$ for $40 \mathrm{~s}$ and $72^{\circ} \mathrm{C}$ for $1 \mathrm{~min}$, concluding with a final extension step at $72{ }^{\circ} \mathrm{C}$ for $10 \mathrm{~min}$.

\section{Molecular detection and characterization of Blastocystis sp.} Identification of Blastocystis sp. was achieved by a direct PCR protocol targeting the SSU rRNA gene of the parasite [25]. The assay uses the pan-Blastocystis, barcode primer pair RD5/BhRDr to amplify a PCR product of $\sim 600 \mathrm{bp}$. Amplification reactions $(25 \mu \mathrm{l})$ included $5 \mu \mathrm{l}$ of template DNA and $0.5 \mu \mathrm{M}$ of each primer (Additional file 1: Table S1). Amplification conditions consisted of one step at $95^{\circ} \mathrm{C}$ for $3 \mathrm{~min}$, followed by 30 cycles of $1 \mathrm{~min}$ each at $94{ }^{\circ} \mathrm{C}, 59^{\circ} \mathrm{C}$ and $72{ }^{\circ} \mathrm{C}$, and a final extension step at $72{ }^{\circ} \mathrm{C}$ for $2 \mathrm{~min}$.

\section{Molecular detection of Neobalantidium coli}

Detection of $N$. coli was attempted by a direct PCR assay to amplify the complete ITS1-5.8S-ITS2 rRNA region and the last $117 \mathrm{bp}\left(3^{\prime}\right.$-end) of the $S S U$-rRNA sequence of this ciliate using the primer set B5D/B5RC [26]. PCR reactions $(25 \mu \mathrm{l})$ consisted of $2 \mu \mathrm{l}$ of template DNA and $0.4 \mu \mathrm{M}$ of each primer (Additional file 1: Table S1). PCR conditions were as follows: $94{ }^{\circ} \mathrm{C}$ for $10 \mathrm{~min}, 30$ cycles of $94{ }^{\circ} \mathrm{C}$ for $1 \mathrm{~min}, 60^{\circ} \mathrm{C}$ for $1 \mathrm{~min}, 72{ }^{\circ} \mathrm{C}$ for $1 \mathrm{~min}$, and a final extension step at $72{ }^{\circ} \mathrm{C}$ for $5 \mathrm{~min}$.

All the direct, semi-nested, and nested PCR protocols described above were conducted on a 2720 Thermal Cycler (Applied Biosystems). Reaction mixes always included 2.5 units of $\mathrm{MyTAQ}^{\mathrm{TM}}$ DNA polymerase
(Bioline $\mathrm{GmbH}$, Luckenwalde, Germany), and $5 \times$ MyTAQ $^{\mathrm{TM}}$ reaction buffer containing $5 \mathrm{mM}$ dNTPs and $15 \mathrm{mM} \mathrm{MgCl}_{2}$. Laboratory-confirmed positive and negative DNA samples for each parasite species investigated were routinely used as controls and included in each round of PCR. PCR amplicons were visualized on 2\% D5 agarose gels (Conda, Madrid, Spain) stained with Pronasafe nucleic acid staining solution (Conda). Positive PCR products were directly sequenced in both directions using appropriate internal primer sets (Additional file 1: Table S1). DNA sequencing was conducted by capillary electrophoresis using BigDye ${ }^{\circledR}$ Terminator chemistry (Applied Biosystems) on an on ABI PRISM 3130 Genetic Analyzer.

\section{Molecular detection of Strongyloides spp}

Identification of Strongyloides spp. was carried out by a qualitative qPCR method using genus-specific primers targeting a $101 \mathrm{bp}$ fragment of the SSU rRNA gene of the parasite [27] using SybrGreen reagents (Invitrogen, San Diego CA, USA) as described elsewhere [28]. qPCR reactions $(25 \mu \mathrm{l})$ contained $10 \mu \mathrm{l}$ of template DNA, $0.2 \mu \mathrm{M}$ of each primer Stro18S-1530F/Stro18S-1630R (Additional file 1: Table S1), 1× Quantimix EasyMaster mix (Biotools B\&M Laboratories, Madrid, Spain), and $0.5 \mu \mathrm{l}$ of $50 \times$ SybrGreen (Invitrogen). All DNA specimens were assayed in duplicate. Positive, negative, and no template controls were included in each run. The amplification program consisted of $15 \mathrm{~min}$ at $95{ }^{\circ} \mathrm{C}$, followed by 50 cycles of $10 \mathrm{~s}$ at $95{ }^{\circ} \mathrm{C}, 10 \mathrm{~s}$ at $60{ }^{\circ} \mathrm{C}$ and $30 \mathrm{~s}$ at $72{ }^{\circ} \mathrm{C}$. DNA amplification and data analyses were as described above for the detection of $G$. duodenalis.

The sequences obtained in this study have been deposited in GenBank under accession numbers MT108431MT108433 (G. duodenalis), MT112069-MT112074 (N. coli), MT114474-MT114479 (Cryptosporidium spp.) and MT114480-MT114489 (Blastocystis sp.).

\section{Statistical analysis}

The prevalence of each intestinal parasite species in the surveyed black Iberian pig and wild boar populations was calculated from the proportion of positive samples with respect to the total number of samples analysed with $95 \%$ confidence interval $(95 \% \mathrm{CI})$. The prevalence was also calculated by animal type (sows and fattening pigs, in the case of black Iberian pigs), sex and age group. These categorical variables were expressed as percentages and the frequencies were compared using the Chi-square or Fisher's tests. The statistical significance was established at a $P$-value $<0.05$. A logistic regression model for HEV infection was performed in the whole population and sorting population in black Iberian pigs and wild boars. Analyses 
were carried out using SPSS statistical software package version 18.0 (IBM Corporation, Somers, NY, USA).

\section{Results}

\section{Study population}

A total of 328 animals were included in the study. Of these, $56.7 \%$ (186/328) were black Iberian pigs, and 43.3\% (142/328) wild boars. Among pigs, 52.7\% (98/186) were sows and $47.3 \%(88 / 186)$ fattening individuals. Respective to wild boars, $42.8 \%$ (48/112) were males and $57.2 \%$ $(64 / 112)$ females. However, sex was unknown for 30 animals. According to age, 47.2\% (67/142) were juveniles and $52.8 \%(75 / 142)$ adults.

\section{Prevalence of HEV and enteroparasites}

The overall prevalence of $\mathrm{HEV}$ in serum and feces was $16.8 \%(55 / 328)$ and $9.1 \%(30 / 328)$, respectively. No statistically significant differences were observed between wild boars and black Iberian pigs in prevalence of HEV in serum (16.9 vs $16.7 \%$; $P=0.99)$ or feces (7.7 vs $10.2 \%$; $P=0.563)$. In total, $73(22.3 \%)$ of the animals were positive for HEV in serum and/or feces [22.6\% (42/186) black Iberians pigs and $21.8 \%(31 / 142)$ wild boars $(P=0.894)]$. As previously described, differences in HEV prevalence were not found in relation to age and sex in both black Iberian pigs and wild boars host $[18,19]$.

In Table 1, the PCR-based prevalence rates for G. duodenalis, Cryptosporidium spp., Blastocystis sp., N. coli and Strongyloides spp. are shown. Pigs had a higher prevalence of Blastocystis sp. (73.1 vs 0.7\%; $P<0.001)$, N. coli $(52.7$ vs $11.7 \%$; $P<0.001)$, and Strongyloides spp. (11.8 vs 4.9\%; $P=0.032$ ) than wild boars. Among black Iberian pigs, the prevalence of G. duodenalis was higher in sows than in fattening pigs (29.5 vs 6.1\%; $P<0.001)$. In contrast, the prevalence of Blastocystis sp. was higher in fattening pigs than in sows $(81.6$ vs $63.6 \% ; P=0.008)$. Regarding wild boars, males were significantly more infected by $N$. coli than females $(23.3$ vs $7.8 \% ; P=0.044)$ and adults than nonadults $(18.3$ vs $4.5 \% ; P=0.016)$. In this host population, the prevalence of G. duodenalis was significantly higher in non-adults than in adults (34.3 vs 12.0\%; $P=0.002)$.

\section{Molecular characterization of detected enteroparasites}

Swine G. duodenalis-positive samples by qPCR generated quantification cycle $(\mathrm{Cq})$ values ranging from 26.0 to 41.2 (median: 35.2). Of these, 9.4\% (6/64) produced Cq values between $25-30,34.4 \%(22 / 64)$ between $>30-35$, and $56.2 \%(36 / 64)>35$. Out of the 32 G. duodenalis-positive samples from black Iberian pigs only 3 were successfully genotyped, revealing the presence of assemblages A $(n=1)$ and $\mathrm{E}(n=2)$ at the $g d h$ and/or $b g$ (but not the tpi) loci (Table 2). These three samples had qPCR Cq values of 26.0, 28.3 and 30.8 , respectively. The sample assigned to assemblage A belonged to the sub-assemblage AI (Additional file 2: Table S2). None of the 32 G. duodenalis-positive samples from wild boars could be genotyped.

Cryptosporidium scrofarum was the only Cryptosporidium species detected in black Iberian pigs (Table 2). Out of the 18 sequences analysed, 17 were identical to the GenBank reference sequence KF597530, whereas one showed a single nucleotide polymorphism (SNP) at position $440(\mathrm{C} / \mathrm{T})$ (Additional file 3: Table S3). Two Cryptosporidium species were found circulating in wild boars: C. scrofarum $(n=8)$ and $C$. suis $(n=1)$ (Table 2). Six of the C. scrofarum sequences showed $100 \%$ homology with GenBank sequence KF597530, whereas two had a single SNP at positions 403 (A/W) and 441 (A/G), respectively (Additional file 3: Table S3). The $C$. suis sequence differed from murine $C$. occultus

Table 1 Prevalence of enteroparasite species in the studied swine (black Iberian pig and wild boar) populations

\begin{tabular}{|c|c|c|c|c|}
\hline Species/subtype & $\begin{array}{l}\text { Total population }(n=328) \\
n(\%)\end{array}$ & $\begin{array}{l}\text { Black Iberian pigs }(n=186) \\
n(\%)\end{array}$ & $\begin{array}{l}\text { Wild boars }(n=142) \\
n(\%)\end{array}$ & $P$-value \\
\hline Giardia duodenalis & $64(19.5)$ & $32(17.2)$ & $32(22.5)$ & 0.261 \\
\hline Cryptosporidium spp. & $27(8.2)$ & $18(9.7)$ & $9(6.3)$ & 0.351 \\
\hline C. scrofarum & $26(96.2)$ & $18(100)$ & $8(88.8)$ & 0.216 \\
\hline C. suis & $1(3.8)$ & $0(0)$ & $1(11.2)$ & \\
\hline Blastocystis sp. & $137(41.8)$ & $136(73.1)$ & $1(0.7)$ & $<0.001$ \\
\hline ST1 & $7(5.1)$ & $7(5.1)$ & $0(0)$ & 0.99 \\
\hline ST3 & $20(14.7)$ & $20(14.7)$ & $0(0)$ & \\
\hline ST5 & $110(80.2)$ & $109(80.1)$ & $1(100)$ & \\
\hline Neobalantidium colia & $103(31.4)$ & $87(52.7)$ & $16(11.7)$ & $<0.001$ \\
\hline Strongyloides spp. & $29(8.8)$ & $22(11.8)$ & $7(4.9)$ & 0.032 \\
\hline
\end{tabular}

${ }^{a}$ Available in 302 individuals

Note: Bold values denote statistical significance at the $P<0.05$ level 
Table 2 Diversity and frequency of parasite species/genotypes identified in the black Iberian pig and wild boar population investigated in the present study

\begin{tabular}{llll}
\hline Host species & Parasite species & Genotype & $n$ \\
\hline Black Iberian pig & Giardia duodenalis & A & 1 \\
& & E & 2 \\
& Cryptosporidium scrofarum & - & 18 \\
& Blastocystis sp. & ST1 & 7 \\
& & ST3 & 20 \\
Wild boar & Cryptosporidium scrofarum & - & 109 \\
& Cryptosporidium suis & - & 8 \\
& Blastocystis sp. & ST5 & 1 \\
\hline
\end{tabular}

Abbreviation: $\mathrm{n}$, number of isolates

(GenBank reference sequence MG699179) by a deletion in 486-489_DelATTA (Additional file 3: Table S3).

Three Blastocystis subtypes (ST) were identified in the 136 black Iberian pigs that carried the parasite, ST1 (5.1\%), ST3 (14.7\%) and ST5 (80.2\%) (Table 2). Further sequence analyses revealed the presence of allele 4 within ST1, alleles 34 and 52 within ST3, and alleles $16,17,115,119,16+17$, and $115+119$ within ST5. Allele 119 was the most prevalent (69.3\%), followed by allele 34 (4.4\%), and allele 4 (3.6\%) (Additional file 4: Table S4). Blastocystis sp. was only found in a wild boar that carried ST5 allele 115 . This very same allele was also detected in a single black Iberian pig.

\section{Interaction between HEV and enteroparasites}

We investigated the interaction between HEV and enteroparasite carriage/infections (Table 3). Animals infected by HEV showed a significantly lower prevalence of $G$. duodenalis (3.2 vs 20\%; $P=0.002)$ and Blastocystis sp. (39 vs $80 \% ; P<0.001$ ) than those animals uninfected by $\mathrm{HEV}$. Interestingly, this association was observed with detectable HEV in serum but not in faeces, suggesting a role on active HEV infection. By multivariate analysis, we identified carriage/infection with G. duodenalis and Blastocystis sp. as a protective factor associated with detectable HEV RNA in serum both in the global swine (black Iberian pigs and wild boars) population and in the black Iberian pig population alone (Table 4). Of note, no significant associations were demonstrated between HEV and the intracellular parasite Cryptosporidium spp. In wild boars, the only factor associated with HEV infection was male sex.

Animals were grouped according to G. duodenalis and Blastocystis sp. status as: (i) positive for both

Table 3 Prevalence of detectable HEV RNA in faeces, serum, and overall, according to presence of the enteroparasite species analysed

\begin{tabular}{|c|c|c|c|c|c|c|c|c|c|}
\hline Positive for & $\begin{array}{l}\mathrm{HEV}+ \\
n(\%)\end{array}$ & $\begin{array}{l}\text { HEV- } \\
n(\%)\end{array}$ & $P$-value & $\begin{array}{l}\text { HEVs+ } \\
n(\%)\end{array}$ & $\begin{array}{l}\text { HEVs- } \\
n(\%)\end{array}$ & $P$-value & $\begin{array}{l}\text { HEVf+ } \\
n(\%)\end{array}$ & $\begin{array}{l}\text { HEVf- } \\
n(\%)\end{array}$ & $P$-value \\
\hline \multicolumn{10}{|l|}{ Global swine population } \\
\hline Giardia duodenalis & $8(11.0)$ & $56(22.0)$ & 0.044 & $4(7.3)$ & $60(22)$ & 0.014 & $4(13.3)$ & $60(20.1)$ & 0.473 \\
\hline Cryptosporidium spp. & $7(9.6)$ & $20(7.8)$ & 0.632 & $5(9.1)$ & $22(8.1)$ & 0.789 & $3(10.0)$ & $24(8.1)$ & 0.725 \\
\hline Blastocystis sp. & $22(30.1)$ & $115(45.1)$ & 0.023 & $12(21.8)$ & $125(45.8)$ & 0.001 & $15(50.0)$ & $122(40.9)$ & 0.340 \\
\hline Neobalantidium spp. ${ }^{a}$ & $23(32.9)$ & $80(34.5)$ & 0.886 & $17(32.1)$ & $86(34.5)$ & 0.873 & $9(31.0)$ & $94(34.4)$ & 0.838 \\
\hline Strongyloides spp. & $5(6.8)$ & $24(9.4)$ & 0.642 & $3(5.5)$ & $26(9.5)$ & 0.440 & $3(10.0)$ & $26(8.7)$ & 0.738 \\
\hline \multicolumn{10}{|l|}{ Black Iberian pigs } \\
\hline Giardia duodenalis & $3(7.1)$ & $29(20.1)$ & 0.062 & $1(3.2)$ & $31(20.0)$ & 0.020 & $2(10.5)$ & $30(18.0)$ & 0.537 \\
\hline Cryptosporidium spp. & $3(7.1)$ & $15(10.4)$ & 0.768 & $3(9.7)$ & $15(9.7)$ & 0.990 & $1(5.3)$ & $17(10.2)$ & 0.700 \\
\hline Blastocystis sp. & $22(52.4)$ & $114(79.2)$ & 0.001 & $12(38.7)$ & $124(80.0)$ & $<0.001$ & 15 (78.9) & $121(72.5)$ & 0.785 \\
\hline Neobalantidium spp. ${ }^{\text {b }}$ & $18(43.9)$ & $69(55.6)$ & 0.210 & $13(41.9)$ & $74(55.2)$ & 0.232 & $8(44.4)$ & $79(53.7)$ & 0.467 \\
\hline Strongyloides spp. & $4(9.5)$ & $18(12.5)$ & 0.788 & $3(9.7)$ & $19(12.3)$ & 0.990 & $2(10.5)$ & $20(12.0)$ & 0.990 \\
\hline \multicolumn{10}{|l|}{ Wild boars } \\
\hline Giardia duodenalis & $5(16.1)$ & $27(24.3)$ & 0.467 & $3(12.5)$ & $29(24.6)$ & 0.285 & $2(18.2)$ & $30(22.9)$ & 0.990 \\
\hline Cryptosporidium spp. & $4(12.9)$ & $5(4.5)$ & 0.105 & $2(8.3)$ & $7(5.9)$ & 0.648 & $2(18.2)$ & $7(5.3)$ & 0.146 \\
\hline Blastocystis sp. & $0(0)$ & $1(0.9)$ & 0.990 & $0(0)$ & $1(0.8)$ & 0.990 & $0(0)$ & $1(0.8)$ & 0.990 \\
\hline Neobalantidium spp. ${ }^{c}$ & $5(17.2)$ & $11(10.2)$ & 0.330 & $4(18.2)$ & $12(10.4)$ & 0.290 & $1(9.1)$ & $15(11.9)$ & 0.990 \\
\hline Strongyloides spp. & $1(3.2)$ & $6(5.4)$ & 0.990 & $0(0)$ & $7(5.9)$ & 0.602 & $1(9.1)$ & $6(4.6)$ & 0.439 \\
\hline
\end{tabular}

a Available in 302 swines

b Available in 165 black lberian pigs

c Available in 137 wild boars

Note: Bold values denote statistical significance at the $P<0.05$ level

Abbreviations: $\mathrm{HEV}$, hepatitis E virus; $\mathrm{HEVs}+$, positive serum samples for hepatitis Evirus; $\mathrm{HEVf}+$, positive faecal samples for hepatitis Ev virus 
Table 4 Multivariate analysis on HEV infection in the global, black Iberian pig, and wild boar populations

\begin{tabular}{|c|c|c|c|c|}
\hline Variable & Condition & OR & $95 \% \mathrm{Cl}$ & $P$-value \\
\hline \multicolumn{5}{|l|}{ Global swine population } \\
\hline Giardia duodenalis & Negative & 0.224 & $0.06-0.754$ & 0.016 \\
\hline Cryptosporidium spp. & Negative & 1.062 & $0.334-3.377$ & 0.918 \\
\hline Blastocystis sp. & Negative & 0.298 & $0.133-0.665$ & 0.003 \\
\hline Neobalantidium spp. & Negative & 1.474 & $0.703-3.089$ & 0.304 \\
\hline Strongyloides spp. & Negative & 0.862 & $0.238-3.126$ & 0.822 \\
\hline \multicolumn{5}{|l|}{ Black Iberian pigs } \\
\hline Giardia duodenalis & Negative & 0.125 & $0.015-1.036$ & 0.054 \\
\hline Cryptosporidium spp. & Negative & 2.182 & $0.489-9.736$ & 0.307 \\
\hline Blastocystis sp. & Negative & 0.163 & $0.06-0.421$ & $<0.001$ \\
\hline Neobalantidium spp. & Negative & 0.874 & $0.336-2.273$ & 0.783 \\
\hline Strongyloides spp. & Negative & 1.073 & $0.263-4.383$ & 0.921 \\
\hline Type of pig & Sow & 2.148 & $0.851-5.421$ & 0.105 \\
\hline \multicolumn{5}{|l|}{ Wild boars } \\
\hline Giardia duodenalis & Negative & 0.778 & $0.081-7.428$ & 0.328 \\
\hline Cryptosporidium spp. & Negative & 1.011 & $0.1-10.254$ & 0.313 \\
\hline Blastocystis sp. & Negative & - & - & - \\
\hline Neobalantidium spp. & Negative & 1.125 & $0.295-4.29$ & 0.476 \\
\hline Strongyloides spp. & Negative & - & - & - \\
\hline Sex & Male & 2.940 & $1.028-8.408$ & 0.034 \\
\hline Age & Juvenile & 1.042 & $0.335-3.235$ & 0.356 \\
\hline
\end{tabular}

Note: Bold values denote statistical significance at the $P<0.05$ level

Abbreviations: $\mathrm{OR}$, odds ratio; $\mathrm{Cl}$, confidence interval

enteroparasites; (ii) positive for at least one enteroparasite; and (iii) negative for both enteroparasites. Overall, $46.3 \%(152 / 328)$ of the tested animals were negative for both G. duodenalis and Blastocystis sp., 46.0\% (151/328) animals tested positive for one of them, and $7.6 \%(25 / 328)$ were positive for both eukaryotes. The prevalence of detectable HEV RNA in serum in these three groups is shown for the total swine (Fig. 1a) and in the black Iberian pig (Fig. 1b) populations. Animals with detectable G. duodenalis and Blastocystis sp. showed a significantly lower rate of $\mathrm{HEV}$ infection than those not bearing these enteroparasites $(P<0.001)$.

\section{Discussion}

Regarding the occurrence of intestinal parasites, the protozoan G. duodenalis and Cryptosporidium spp. were detected at similar rates in the investigated swine populations (17 vs 23\% and 6 vs 10\%, respectively). Based on the qPCR Cq values obtained, G. duodenalis seems to be present mostly as a light infection. In Spain, Cryptosporidium infections have been reported by microscopy examination at rates of $23 \%$ in farmed pigs in north-eastern Spain [29], and of $18 \%$ in wild boar populations in the Galicia autonomous region (north-western Spain) [30,

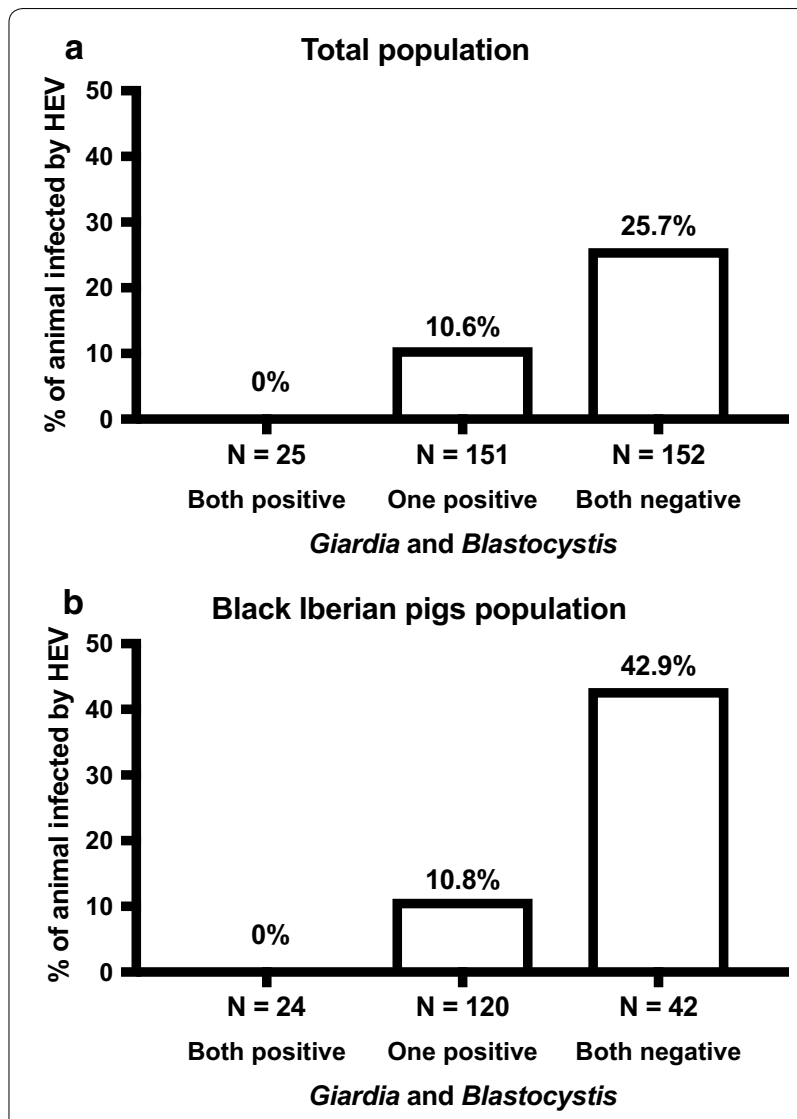

Fig. 1 Prevalence of detectable hepatitis E virus RNA in serum in the overall population (a) and black Iberian pigs (b) according to Giardia duodenalis and Blastocystis sp. status

31]. Giardia duodenalis infections/cysts have been identified in wild boars from the latter Spanish region at a rate of $8 \%$ [30], and in slurry from intensive pig farms [32]. In our study Blastocystis sp. was very common in black Iberian pigs but almost absent in wild boars (73 vs $0.7 \%$ ). Additionally, the Blastocystis sp. prevalence observed in our black Iberian pig population was considerably higher than those (7-47\%) previously described in intensively reared pigs in other Spanish regions [33, 34].

Following the same trend observed for Blastocystis sp. (although to a lesser extent) infection rates of $N$. coli and Strongyloides spp. were substantially lower in wild boars compared with those observed in black Iberian pigs. Neobalantidium coli is widely recognized as a very common opportunistic parasite of domestic pigs, where infections are mostly subclinical (balantidial dysentery is rare), and is therefore considered of limited veterinary relevance in high-income countries [7]. This is, to the best of our knowledge, the first PCR-based report of $N$. coli in wild boars in Spain. The finding of Strongyloides spp. in both swine populations was also interesting. 
Porcine strongyloidosis by S. suis (syn. S. ransomi) is known to infect domestic pigs and wild boars globally, usually at low levels [35].

Regarding molecular data, this is, to the best of our knowledge, the first report of G. duodenalis assemblages $A$ and $E$ in Spanish black Iberian pigs. Two Cryptosporidium species were identified. Black Iberian pigs were exclusively infected by $C$. scrofarum, whereas wild boars harboured both $C$. scrofarum and C. suis. Both species have been previously identified in asymptomatic farmed pigs in north-eastern Spain [29], and C. suis in wild boars in north-western Spain [31]. This study also provides the first molecular data on the occurrence and genetic diversity of Blastocystis sp. in black Iberian pigs. As expected, ST5 was identified as the most prevalent genetic variant of the parasite, followed by the zoonotic ST3 and ST1. Both ST1 and ST3 have been identified in asymptomatic, mostly paediatric, populations in Spain [36, 37]. Of interest, the finding of ST5 in the only wild boar demonstrated to carry the parasite may be indicative of transmission between black Iberian pigs and wild boars in this geographical area.

The most important contribution of this study is the striking interaction observed between HEV and intestinal extracellular parasites. Specifically, both G. duodenalis and Blastocystis sp. seem to modulate the rate of HEV infection (or vice versa) in swine in general, and in Black Iberian pigs in particular. Such association was not observed between HEV and the intracellular parasite Cryptosporidium spp. At present we cannot demonstrate the directionality of this interaction, but we favour the hypothesis of parasites modulating viral infection based on previous reports in the literature. A similar association was found in a study conducted in Israel, where $G$. duodenalis (but not Cryptosporidium spp.) modulated the severity of infection with some enteric pathogens in children under two years of age [38]. In that survey, episodes with rotavirus alone were more severe as compared to episodes when rotavirus was in a co-infection with $G$. duodenalis. The reason for this possible association is completely unknown.

It has been demonstrated that several microorganisms could impair the establishment of the infection by other pathogens. This is the case of the GB virus competing with HIV for CD4+ receptors in the surface of lymphocytes. This rivalry impairs the efficiency of the HIV cycle, delaying the progression of the disease to AIDS [39]. In this sense, our results could fit with this mechanism. We hypothesize a competition between intestinal parasites and HEV as a possible explanation of the modulation of the rate of infection, through a biochemical or physical barrier. In fact, a recent study suggests that G. duodenalis can reduce colitis by Escherichia coli through the expression and secretion of antimicrobial peptides by the host's intestinal epithelial cells via the release of parasite's cathepsin B-like cysteine protease that directly inhibits the growth of the bacteria [40]. In addition, G. duodenalis infection has been shown to modulate host pro-inflammatory responses to pathogenic bacteria and pro-inflammatory stimuli. For instance, the parasite was able to reduce granulocyte infiltration in an in vivo model of bacterial toxin-induced colitis and attenuate inflammation in human intestinal tissue [41]. Secretion of G. duodenalis cathepsin B cysteine proteases can also attenuate secretion of the neutrophil chemoattractant interleukin- 8 in human small intestinal mucosal tissues activated through administration of Salmonella enterica serovar Typhimurium [42]. Finally, G. duodenalis has been demonstrated to inhibit epithelial nitric oxide production, a common host defence against pathogen infection, by consuming arginine, the crucial substrate to generate the compound [43]. Studies evaluating this possible protective effect of enteroparasites on HEV infection are warranted. Nextgeneration sequencing data using the $16 S$ and $18 S$ rRNA genes can provide a deeper insight into potential interactions between these pathogens and the host-associated microbial communities.

It should be noted that conclusions drawn in this survey may be biased by some factors. First, although relatively large sample sizes of black Iberian pigs and wild boars were analysed, the limited number of positive cases identified for some enteroparasites (Cryptosporidium spp. and Strongyloides spp.) may hinder the significance of associated risk factors. Secondly, the Strongyloides qPCR method used here, originally used to identify $S$. stercoralis in human faecal samples with genus-specific primers, has not been systematically tested with faecal material from non-human sources. This fact, together with the lack of sequencing data (the 101-bp amplicon is not informative enough to discriminate among different Strongyloides species) does not allow as to accurately determine the species of this nematode involved in the infections. Thirdly, we did not quantify the G. duodenalis and Blastocystis sp. burden in the investigated hosts. It would be very interesting to see how parasite burdens correlate with HEV infection rates. This question should be addressed in future surveys.

\section{Conclusions}

Our study found a high prevalence of enteroparasites in pigs and wild boars from southern Spain. The genetic diversity analyses carried out strongly suggest the sympatric co-transmission of some of the species investigated (Cryptosporidium scrofarum and, to a lesser extent, 
Blastocystis sp.). It is hypothesized that extracellular G. duodenalis and Blastocystis sp. might have a protective effect on HEV acquisition in swine. The extent and directionality of this finding needs to be confirmed and further investigated in well-designed case-control studies.

\section{Supplementary information}

Supplementary information accompanies this paper at https://doi. org/10.1186/s13071-020-04152-9.

Additional file 1: Table S1. Oligonucleotides used for the molecular identification and/or characterization of the intestinal protist and helminth parasites investigated in the present study.

Additional file 2: Table S2. Diversity, frequency, and main molecular features of $G$. duodenalis isolates in swine samples. GenBank accession numbers of representative sequences are provided. Novel genotypes are underlined.

Additional file 3: Table S3. Diversity, frequency, and main molecular features of Cryptosporidium isolates at the SSU rRNA loci in swine samples. GenBank accession numbers of representative sequences are provided. Novel genotypes are underlined.

Additional file 4: Table S4. Diversity and frequency of Blastocystis sp. subtypes and 185 alleles identified in the present study.

\section{Abbreviations}

bg: B-giardin; Cq: quantification cycle; gdh: glutamate dehydrogenase; HEV: hepatitis E virus; qPCR: real-time polymerase chain reaction; SSU rRNA: small subunit ribosomal RNA; ST: subtype; tpi: triose phosphate isomerase.

\section{Acknowledgements}

Antonio Rivero-Juarez is the recipient of a Miguel Servet Research Contract by the Ministerio de Ciencia, Promoción y Universidades of Spain (CP18/00111).

\section{Authors' contributions}

$A R J, V B, R C B, D G B$, JMS and DC identified the research question and selected the methodology to be used. AD, ASM, BB, MHdM and ED performed the experimental work. PCK conducted sequence analyses. ARJ, VB and DC wrote the original draft of the manuscript. All authors contributed to the critical review of the results. All authors read and approved the final manuscript.

\section{Funding}

This study was funded by the Health Institute Carlos III (ISCIII), Ministry of Economy and Competitiveness (Spain), under project PI16CIII/00024.

\section{Availability of data and materials}

All relevant data are within the article and its additional files. The sequence data were submitted to the GenBank database under the accession numbers MT108431-MT108433, MT112069-MT112074, and MT114474-MT114489.

\section{Ethics approval and consent to participate}

This study was carried out in accordance with Spanish legislation guidelines (RD 8/2003) and with the International Guiding Principles for Biomedical Research Involving Animals issued by the Council for International Organization of Medical Sciences and the International Council for Laboratory Animal Science (RD 53/2013).

\section{Consent for publication}

Not applicable.

\section{Competing interests}

The authors declare that they have no competing interests.

\section{Author details}

${ }^{1}$ Infectious Diseases Unit, Maimonides Institute for Biomedical Research (IMIBIC), University Hospital Reina Sofía, Córdoba, University of Córdoba,
Córdoba, Spain. ${ }^{2}$ Parasitology Reference and Research Laboratory, Spanish National Centre for Microbiology, Majadahonda, Madrid, Spain. ${ }^{3}$ Department of Anatomy and Compared Pathological Anatomy, University of Córdoba, Agrifood Excellence International Campus (ceiA3), Córdoba, Spain. ${ }^{4}$ Department of Animal Health, Faculty of Veterinary, University of Córdoba-Agrifood Excellence International Campus (ceiA3), Córdoba, Spain. ${ }^{5}$ SALUVET, Department of Animal Health, Faculty of Veterinary, Complutense University of Madrid, Madrid, Spain. ${ }^{6}$ Viral Hepatitis Reference and Research Laboratory, Spanish National Centre for Microbiology, Majadahonda, Madrid, Spain.

Received: 27 March 2020 Accepted: 28 May 2020

Published online: 03 June 2020

\section{References}

1. DuPont HL. Persistent diarrhea: a clinical review. JAMA. 2016;315:2712-23.

2. Santín M. Clinical and subclinical infections with Cryptosporidium in animals. N Z Vet J. 2013;61:1-10

3. Efstratiou A, Ongerth JE, Karanis P. Waterborne transmission of protozoan parasites: review of worldwide outbreaks - an update 2011-2016. Water Res. 2017;114:14-22.

4. Robertson LJ. Parasites in food: from a neglected position to an emerging issue. Adv Food Nutr Res. 2018:86:71-113.

5. Andersen LO, Stensvold CR. Blastocystis in health and disease: are we moving from a clinical to a public health perspective? J Clin Microbiol. 2016;54:524-8

6. Clark CG, van der Giezen M, Alfellani MA, Stensvold CR. Recent developments in Blastocystis research. Adv Parasitol. 2013;82:1-32.

7. Schuster FL, Ramirez-Avila L. Current world status of Balantidium coli. Clin Microbiol Rev. 2008:21:626-38.

8. Kagira JM, Kanyari PN, Githigia SM, Maingi N, Ng'ang'a JC, Gachohi JM. Risk factors associated with occurrence of nematodes in free range pigs in Busia District. Kenya. Trop Anim Health Prod. 2012;44:657-64.

9. WHO. Global hepatitis report 2017. Geneva: World Health Organization; 2017. http://www.who.int/hepatitis/publications/global-hepatitis-repor t2017/en/. Accessed 27 Mar 2020

10. European Food Safety Authority. Public health risks associated with hepatitis E virus (HEV) as a food-borne pathogen. EFSA J. 2017;15:4886.

11. WHO. Waterborne outbreaks of hepatitis E: recognition, investigation and control World Health Organization Technical report. Geneva: World Health Organization; 2014. https://www.who.int/hiv/pub/hepatitis/HepEmanual/en/. Accessed 27 Mar 2020

12. Faber M, Askar M, Stark K. Case-control study on risk factors for acute hepatitis E in Germany, 2012 to 2014. Euro Surveill. 2018;19:17-00469.

13. Hoofnagle JH, Nelson KE, Purcell RH. Hepatitis E. Ne Engl J Med. 2012;367:1237-44

14. Pavio N, Doceul V, Bagdassarian E, Johne R. Recent knowledge on hepatitis $E$ virus in Suidae reservoirs and transmission routes to human. Vet Res. 2017:48:78.

15. Khuroo MS, Kamili S, Khuroo MS. Clinical course and duration of viremia in vertically transmitted hepatitis E virus (HEV) infection in babies born to HEV-infected mothers. J Viral Hepat. 2009:16:519-23.

16. Frias M, López-López P, Rivero A, Rivero-Juarez A. Role of hepatitis E virus infection in acute-on-chronic liver failure. Biomed Res Int. 2018;2018:9098535

17. Rivero-Juarez A, Lopez-Lopez P, Frias M, Rivero A. Hepatitis E infection in HIV-infected patients. Front Microbiol. 2019;10:1425.

18. Lopez-Lopez P, Risalde MLA, Frias M, García-Bocanegra I, Brieva T, Caballero-Gomez J, et al. Risk factors associated with hepatitis E virus in pigs from different production systems. Vet Microbiol. 2018;224:88-92.

19. Rivero-Juarez A, Risalde MA, Frias M, García-Bocanegra I, Lopez-Lopez P, Cano-Terriza D, et al. Prevalence of hepatitis E virus infection in wild boars from Spain: a possible seasonal pattern. BMC Vet Res. 2018;14:54.

20. Verweij JJ, Schinkel J, Laeijendecker D, van Rooyen MA, van Lieshout L, Polderman AM. Real-time PCR for the detection of Giardia lamblia. Mol Cell Probes. 2003;17:223-5.

21. Read CM, Monis PT, Thompson RC. Discrimination of all genotypes of Giardia duodenalis at the glutamate dehydrogenase locus using PCRRFLP. Infect Genet Evol. 2004:4:125-30. 
22. Lalle M, Pozio E, Capelli G, Bruschi F, Crotti D, Cacciò SM. Genetic heterogeneity at the beta-giardin locus among human and animal isolates of Giardia duodenalis and identification of potentially zoonotic subgenotypes. Int J Parasitol. 2005;35:207-13.

23. Sulaiman IM, Fayer R, Bern C, Gilman RH, Trout JM, Schantz PM, et al. Triosephosphate isomerase gene characterization and potential zoonotic transmission of Giardia duodenalis. Emerg Infect Dis. 2003;9:1444-52.

24. Tiangtip R, Jongwutiwes S. Molecular analysis of Cryptosporidium species isolated from HIV-infected patients in Thailand. Trop Med Int Health. 2002;7:357-64.

25. Scicluna SM, Tawari B, Clark CG. DNA barcoding of Blastocystis. Protist. 2006;157:77-85

26. Ponce-Gordo F, Fonseca-Salamanca F, Martínez-Díaz RA. Genetic heterogeneity in internal transcribed spacer genes of Balantidium coli (Litostomatea, Ciliophora). Protist. 2011;162:774-94.

27. Verweij JJ, Canales M, Polman K, Ziem J, Brienen EA, Polderman AM, et al. Molecular diagnosis of Strongyloides stercoralis in faecal samples using real-time PCR. Trans R Soc Trop Med Hyg. 2009;103:342-6.

28. Saugar JM, Merino FJ, Martín-Rabadán P, Fernández-Soto P, Ortega S, Gárate T, et al. Application of real-time PCR for the detection of Strongyloides spp. in clinical samples in a reference center in Spain. Acta Trop. 2015:42:20-5.

29. Suárez-Luengas L, Clavel A, Quílez J, Goñi-Cepero MP, Torres E, SánchezAcedo C, et al. Molecular characterization of Cryptosporidium isolates from pigs in Zaragoza (northeastern Spain). Vet Parasitol. 2007;148:231-5.

30. Castro-Hermida JA, García-Presedo I, González-Warleta M, Mezo M. Prevalence of Cryptosporidium and Giardia in roe deer (Capreolus capreolus) and wild boars (Sus scrofa) in Galicia (NW, Spain). Vet Parasitol. 2011;179:216-9.

31. García-Presedo I, Pedraza-Díaz S, González-Warleta M, Mezo M, GómezBautista M, Ortega-Mora LM, et al. Presence of Cryptosporidium scrofarum, C. suis and C. parvum subtypes llaA16G2R1 and IlaA13G1R1 in Eurasian wild boars (Sus scrofa). Vet Parasitol. 2013;196:497-502.

32. Reinoso $R$, Becares $E$. The occurrence of intestinal parasites in swine slurry and their removal in activated sludge plants. Bioresour Technol. 2008:99:6661-5.

33. Quilez J, Clavel A, Sanchez-Acedo C, Causape AC. Detection of Blastocystis sp. in pigs in Aragon (Spain). Vet Parasitol. 1995;56:345-8.

34. Navarro C, Domínquez-Márquez MV, Garijo-Toledo MM, Vega-García S, Fernández-Barredo S, Pérez-Gracia MT, et al. High prevalence of Blastocystis sp. in pigs reared under intensive growing systems: frequency of ribotypes and associated risk factors. Vet Parasitol. 2008;153:347-58.

35. Thamsborg SM, Ketzis J, Horii Y, Matthews JB. Strongyloides spp. infections of veterinary importance. Parasitology. 2017;144:274-84.
36. Paulos S, Köster PC, de Lucio A, Hernández de Mingo M, Cardona GA, Fernández-Crespo JC, et al. Occurrence and subtype distribution of Blastocystis sp. in humans, dogs and cats sharing household in northern Spain and assessment of zoonotic transmission risk. Zoo Public Health. 2018;65:993-1002.

37. Muadica AS, Köster PC, Dashti A, Bailo B, Hernández de Mingo M, Reh $L$, et al. Molecular diversity of Giardia duodenalis, Cryptosporidium spp. and Blastocystis sp. in asymptomatic school children in Leganés, Madrid (Spain). Microorganisms. 2020;8:466.

38. Bilenko N, Levy A, Dagan R, Deckelbaum RJ, El-On Y, Fraser D. Does co-infection with Giardia lamblia modulate the clinical characteristics of enteric infections in young children? Eur J Epidemiol. 2004;19:877-83.

39. Xiang J, Wünschmann S, Diekema DJ, Klinzman D, Patrick KD, George SL, et al. Effect of coinfection with GB virus $C$ on survival among patients with HIV infection. N Eng J Med. 2001;345:707-14.

40. Manko A, Motta JP, Cotton JA, Feener T, Oyeyemi A, Vallance BA, et al. Giardia co-infection promotes the secretion of antimicrobial peptides beta-defensin 2 and trefoil factor 3 and attenuates attaching and effacing bacteria-induced intestinal disease. PLoS ONE. 2017;12:e0178647.

41. Cotton JA, Motta JP, Schenck LP, Hirota SA, Beck PL, Buret AG. Giardia duodenalis infection reduces granulocyte infiltration in an in vivo model of bacterial toxin-induced colitis and attenuates inflammation in human intestinal tissue. PLoS ONE. 2014;9:e109087.

42. Cotton JA, Bhargava A, Ferraz JG, Yates RM, Beck PL, Buret AG. Giardia duodenalis cathepsin B proteases degrade intestinal epithelial interleukin-8 and attenuate interleukin-8-induced neutrophil chemotaxis. Infect Immun. 2014;82:2772-87.

43. Eckmann L, Laurent F, Langford TD, Hetsko ML, Smith JR, Kagnoff MF, et al. Nitric oxide production by human intestinal epithelial cells and competition for arginine as potential determinants of host defense against the lumen-dwelling pathogen Giardia lamblia. J Immunol. 2000;164:1478-87.

\section{Publisher's Note}

Springer Nature remains neutral with regard to jurisdictional claims in published maps and institutional affiliations.

Ready to submit your research? Choose BMC and benefit from:

- fast, convenient online submission

- thorough peer review by experienced researchers in your field

- rapid publication on acceptance

- support for research data, including large and complex data types

- gold Open Access which fosters wider collaboration and increased citations

- maximum visibility for your research: over $100 \mathrm{M}$ website views per year

At BMC, research is always in progress.

Learn more biomedcentral.com/submissions 